\title{
МЕЖДУ АЗИЕЙ И АВСТРАЛИЕЙ (КРАНИОЛОГИЧЕСКОЕ РАЗНООБРАЗИЕ МОЗГОВОГО ЧЕРЕПА СОВРЕМЕННОГО НАСЕЛЕНИЯ ЮГО-ВОСТОЧНОЙ АЗИИ)*
}

\begin{abstract}
Настоящая работа является продолжением серии исследований, посвященных панойкумкенной классификащии современного человека по мозговому черепу. Изучались краниологические особенности близкого к современности населения обширных территорий Юго-восточной Азии, Австралии и островного мира, лежащего между этими континентами. В основном исследование опиралось на сравнительный анализ индивидуальных данных мужских черепов 32 краниосерий, взятых из работ антропологов, изучавщих этот регион. Метрические признаки (абсолютные размеры и индексы) этих краниосерий вычислялись на основе величины трёх взаимноперпендикулярных диаметров черепной коробки, взятых из литературных источников. Восемь остальных признаков рассчитывались по различныл соотношениям величин этих диаметров. Дендрограмма расстояний между этими 32-мя краниосериями, построенная по 11 признакам размера и формы черепной коробки, чётко разбивается на три кластера. Краниосерии одного из них характеризуются параметрами, типичными для панойкуменного краниотипа пацифидов: мезокранные, средневысокие и средне удлинённые черепа. Серии другого кластера представляют краниотип восточных тропидов: долихокранные, средневысокие и сильно удлинённые черепа. Краниосерии третьего кластера отличны как от названных двух панойкуменных краниотипов, так и от третьего панойкуменного краниотипа голарктидов, серии которого отсутствуют на изучаемой территории. Серии этого последнего кластера получили у нас наименование - сундиды, т.к. в основном они локализованы на территории субконтинента Сунда, образованого во время регрессии моря в эпоху четвертичного плейсточена, когда шельфовые моря юго-восточной Азии и Индонезии
\end{abstract}

Пестряков Александр Петрович - к.и.н., старший научный сотрудник Центра физической антропологии, Институт этнологии и антропологии РАН (Москва, Ленинский пр. 32-а) Эл. почта: labrecon@yandex.ru

Григорьева Ольга Михайловна - к.б.н., старший научный сотрудник Центра физической антропологии, Институт этнологии и антропологии РАН (Москва, Ленинский пр. 32-а) Эл. почта: labrecon@yandex.ru

Пеленицына Юлия Вадимовна - студентка кафедры антропологии биологического факультета МГУ им. М.В. Ломоносова (119234 Москва, Ленинские горы, 1/12) Эл. почта: j.pelenitsyna@gmail

* Исследование выполнено в рамках темы НИР «Эволюционный континуум рода Ното». Подтема «Антропология древних и современных популяций» 
стали сушей, частью единого Евразийского континента. Для подобных серий характерна малая величина укороченного брахикранного черепа. Большая часть краниосерий Индокитая и Индонезии могут быть отнесены именно $к$ этому краниотипу. Таким образом, большая монголоидная раса разбивается по признакам мозгового черепа на три различных краниологических типа: континентальные монголоиды (голарктиды), тихоокеанские монголоиды (naиифиды) и южные монголоиды (сундиды).

Ключевые слова: мозговой череп, краниосерия, краниотип, сундиды

Ссылка при цитировании: Липинская В.A. Русское маслоделие (традиции, новации и развитие промышленности) XIX-XX в. // Вестник антропологии, 2021. № 1 (53). С. 166-182.

\section{Введение}

С точки зрения физической географии половина изучаемого нами региона представляет собой огромный (самый большой на планете) островной мир, примыкающий с северо-западной стороны к континенту Евразии, а с юго-восточной к континенту Австралии. Западную половину этого островного мира занимает Малайский архипелаг, состоящий из Больших (Суматра, Ява, Калимантан и Сулавеси) и Малых Зондских, Молуккских островов и Филиппин. Восточная половина этого мира - это остров Новая Гвинея и архипелаги Меланезии. Все острова разделены сравнительно небольшими, часто мелководными шельфовыми морями, но иногда узкими глубоководными морями и проливами. По геологическим временным масштабам ещё недавно, в плейстоцене, по археологической периодике во времена палеолита, из-за общепланетарного похолодания, во многих местах Земли сформировались огромные наземные покровные ледники из замерзшей воды, которая естественно изымалась из океана. Вследствие этого уровень последнего понижался, и значительная часть площади шельфовых морей становились сушей, частью близлежащего материка. Осушенные шельфы западной части Малайского архипелага и Южно-китайского моря соединялись с Евразийским материком. Этот субконтинент получил наименование Сунда. В это же время осушенные шельфы Арафурского моря и Бассова пролива соединяли материк Австралии с Новой Гвинеей и Тасманией. Этот суперматерик назвали Сахул. Эти два больших массива суши разделялись узкими, но глубоководными морями или проливами. Это стало определяющим фактором в эволюционно-биологическом различии природных биоценозов Сунды и Сахула: здесь проходит знаменитая линия Уоллеса.

\section{Материалы и методы}

В настоящей работе анализировались краниосерии изучаемой территории, близкие к современности, но лишь те, где авторами приводятся индивидуальные данные черепов. Изучено 32 мужские серии. Величины наибольших продольных, поперечных и высотных (от базиона) диаметров взяты из работ нижеследующих авторов. В скобках - число черепов в серии. 
Бонин (Bonin 1931): яванцы Батавии $(n=32)$, Бантама $(n=20)$, средней Явы $(n=30)$, сборной серии, в основном с восточной части Явы $(\mathrm{n}=25)$, яванцы острова Мадуpa $(n=15)$, даяки о. Калимантана $(n=36)$, тагалы Филиппин $(n=31)$, аэта Филиппин $(\mathrm{n}=33)$, андаманцы Андаманских островов $(\mathrm{n}=22)$. Харровер (Harrower 1925): китайцы (хакка) Сингапура ( $\mathrm{n}=36)$, тамилы, контрактованные рабочие Сингапура $(\mathrm{n}=35)$. Тидсли (Tidesley 1921): бирманцы ( $\mathrm{n}=42)$. Морант (Morant 1924): тибетцы Непала $(\mathrm{n}=45)$, тибетцы Тибета ( $\mathrm{n}=32)$. Додо (Dodo 2001): японцы о. Окинава $(\mathrm{n}=37)$, японцы островов Сакишима архипелага Рюкю (n=23). Алексеев В.П. (Алексеев 1974, 1982): серия папуасов Новой Гвинеи, собранная Н.Н. Миклухо-Маклаем (n=20), бенгальцы $(\mathrm{n}=32)$. Хамбли (Hambly 1946): меланезийцы о. Амбрим архипелага Новые Гебриды (n=20). Хрдличка А. (Hrdlicka 1928): меланезийцы Новой Британии $(\mathrm{n}=13)$, австралийцы Северной Территории (n=107), австралийцы Квинсленда (n=62), австралийцы Нового Южного Уэллса $(\mathrm{n}=53)$, австралийцы Южной Австралии $(\mathrm{n}=198)$. Исходные данные по остальным восьми сериям взяты из фундаментальной сводки Хауэллса (Howells craniometric data set.): китайцы острова Хайнань ( $\mathrm{n}=45)$, китайцы южные ( $\mathrm{n}=38)$, японцы южные $(\mathrm{n}=50)$, гаошань атаял $(\mathrm{n}=29)$, филиппинцы $(\mathrm{n}=50)$, андаманцы Андаманских островов $(\mathrm{n}=35)$, меланезийцы толай $(\mathrm{n}=50)$, меланезийцы островов Санта-Крус архипелага Соломоновых островов $(\mathrm{n}=50)$.

В работе рассматриваются 11 краниометрических признаков черепной коробки. Величины первых трёх (№ 1, № 8, № 17 по Мартину - наибольшие длина, ширина и высота черепной коробки) брались из соответствующего литературного источника. Все следующие признаки вычислялись по величинам этих трёх. Далее приводятся величины черепного (8:1), высотно- продольного (17:1) и высотно-поперечного (17:8) указателей. Пять следующих метрических признаков используются обычно лишь в работах авторов настоящей статьи. Общая ростовая величина (OPB) черепной коробки количественно выражает физиологическую силу роста, распределённую по трём пространственным осям. Она вычисляется векторным сложением величин основных диаметров черепа $-\mathrm{OPB}=\left(1^{2}+8^{2}+17^{2}\right)^{1 / 2}$. Три следующих указателя: долихоидности (УД), брахиоидности (УБ), гипсиоидности (УГ) представляют собой средние геометрические отношения каждого из трех названных диаметров черепной коробки к двум оставшимся (в \%). Например, УД $=100 *\left[\left(1^{2} /(8 * 17)\right]^{1 / 2}\right.$. И т.п. Последний параметр - степень сферичности (СС) объединяет значения трёх этих указате-

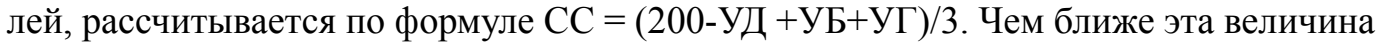
к 100, тем более черепная коробки приближается по форме к сфере. В таблице 1 даны среднегрупповые величины этих признаков.

\section{Результаты и обсуждение}

В ходе проведенного исследования были получены следующие результаты. Были получены среднегрупповые величины изученных краниологических признаков во всех взятых сериях, представленные в таблице 1 .

Кроме среднегрупповых величин изучаемых признаков, в таблице 1 также представлены показатели их межгрупповой изменчивости: межгрупповые средние квадратические отклонения (б), коэффициенты вариации и др., что позволяет оценить в них степень их межгрупповой изменчивости. 
䒕

\begin{tabular}{|c|c|c|c|c|c|c|c|c|c|c|c|c|c|c|c|c|c|c|c|}
\hline u & $\begin{array}{l}\sigma_{0} \\
\infty\end{array}$ & $\tilde{n}_{\infty}^{n}$ & $\bar{n}$ & $\begin{array}{l}0 \\
\infty \\
\infty\end{array}$ & $\hat{\infty}$ & $\underset{\infty}{+}$ & in & $\begin{array}{c}n \\
\infty \\
\infty\end{array}$ & $\begin{array}{c}2 \\
n \\
\infty\end{array}$ & $\begin{array}{l}\infty \\
\infty\end{array}$ & $\stackrel{m}{\infty}$ & $\tilde{\infty}$ & $\begin{array}{c}\infty \\
\infty \\
\infty\end{array}$ & $\underset{\infty}{+}$ & $\stackrel{0}{\infty}$ & $\begin{array}{l}0 \\
\text { N }\end{array}$ & $\begin{array}{l}0 \\
\stackrel{\infty}{\infty}\end{array}$ & $\stackrel{\sim}{\infty}$ & $\begin{array}{l}\infty \\
\infty \\
\infty\end{array}$ \\
\hline 5 & $\begin{array}{c}\hat{\alpha} \\
\infty \\
\infty\end{array}$ & $\frac{2}{\infty}$ & ชู & $\tilde{\infty}^{n}$ & $\infty$ & $\begin{array}{l}0 \\
\infty \\
\infty\end{array}$ & $\frac{\sigma_{n}}{\infty}$ & $\begin{array}{l}\infty \\
\infty \\
\infty\end{array}$ & $\hat{\infty}$ & $\sigma_{\infty}^{+}$ & $\begin{array}{l}n \\
\infty \\
\infty\end{array}$ & $\infty_{\infty}^{\infty}$ & $\frac{n}{\infty}$ & $\begin{array}{c}+ \\
\infty \\
\infty\end{array}$ & $\vec{\infty}$ & $\ddot{\infty}$ & $\stackrel{0}{\infty}_{\infty}$ & $\frac{\sigma_{n}}{\infty}$ & $\begin{array}{l}0 \\
\infty\end{array}$ \\
\hline$\stackrel{0}{\lambda}$ & ๙a & ลू & $\tilde{n}$ & $\begin{array}{l}0 \\
\text { d }\end{array}$ & $n$ & $\stackrel{0}{\infty}$ & $\begin{array}{c}\hat{D}^{2} \\
\infty\end{array}$ & $\begin{array}{l}0 \\
\dot{\Omega}\end{array}$ & $\frac{0}{a}$ & $\begin{array}{c}\infty \\
\alpha \\
\alpha\end{array}$ & $\frac{\infty}{a}$ & $\hat{\infty}$ & مे & $\frac{\infty}{\infty}$ & $\underset{\infty}{\nabla_{\infty}}$ & $\stackrel{\infty}{\infty}$ & $\vec{\infty}$ & $\frac{\sigma_{n}}{\infty}$ & $\begin{array}{l}0 \\
\text { \& }\end{array}$ \\
\hline$\sqrt{x}$ & $\stackrel{\leftarrow}{\stackrel{\sim}{\beth}}$ & $\vec{I}$ & $\stackrel{n}{\stackrel{\Xi}{J}}$ & $\stackrel{n}{\bumpeq}$ & $\stackrel{\sigma_{-}}{\text {I }}$ & กิ & 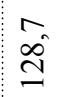 & 仓े & $\hat{\tilde{I}}$ & $\frac{a}{ \pm}$ & $\frac{n}{\beth}$ & $\begin{array}{l}0 \\
\infty \\
0\end{array}$ & $\begin{array}{l}\text { n } \\
\stackrel{0}{N}\end{array}$ & ปे & $\frac{n}{m}$ & $\begin{array}{l}\infty \\
\stackrel{\mathrm{J}}{ }\end{array}$ & กี & $\frac{N}{m}$ & 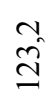 \\
\hline$\stackrel{\infty}{\stackrel{x}{\check{I}}}$ & $\bar{n}$ & हैं & $\begin{array}{l}\text { बे } \\
\text { a }\end{array}$ & $\hat{a}$ & $\tilde{n}$ & $\begin{array}{l}0 \\
\infty \\
\infty\end{array}$ & $\stackrel{\infty}{\infty}$ & $\tilde{2}$ & $\hat{J}^{\prime}$ & $\stackrel{\sigma}{a}$ & $\stackrel{\forall}{a}$ & $\frac{a}{a}$ & $\begin{array}{l}\infty \\
\infty \\
\infty\end{array}$ & 8 & $\stackrel{\nabla_{\infty}}{\infty}$ & $\frac{1}{a}$ & $\begin{array}{l}n \\
\infty \\
\infty\end{array}$ & $\stackrel{0}{8}$ & $\stackrel{\infty}{\mathbb{\sigma}}$ \\
\hline$\ddot{\Xi}$ & $\vec{a}$ & $\vec{\Omega}$ & $\stackrel{m}{\infty}$ & $\infty$ & $\frac{N}{2}$ & $\hat{0}$ & $\stackrel{2}{\stackrel{2}{2}}$ & $\mathfrak{n}^{n}$ & $\begin{array}{l}\sigma^{\prime} \\
\curvearrowright\end{array}$ & $\underset{\infty}{\infty}$ & $\hat{\sigma}$ & $\stackrel{0}{\circ}$ & $\stackrel{n}{\approx}$ & $\stackrel{\infty}{\stackrel{\infty}{n}}$ & 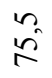 & $\stackrel{\circ}{\circ}$ & $\approx$ & $\overbrace{}^{2}$ & $\stackrel{\sim}{2}$ \\
\hline $\bar{\infty}$ & $\stackrel{\vec{\sigma}}{\tilde{\infty}}$ & $\begin{array}{c}+ \\
\infty \\
\infty\end{array}$ & ĩ & $\frac{\sigma}{\infty}$ & $\tilde{\infty}$ & $\stackrel{n}{\infty}$ & $\vec{\infty}$ & $\vec{r}$ & $\begin{array}{l}0 \\
\mathbb{\infty}^{\prime}\end{array}$ & $\vec{\infty}$ & $\stackrel{+}{\infty}$ & $\underset{\infty}{\infty}$ & $\begin{array}{l}0 \\
\infty\end{array}$ & $\frac{\sigma_{n}}{\stackrel{2}{2}}$ & $\hat{\sigma}$ & $\stackrel{m}{\infty}$ & $\sigma_{0}^{n}$ & $\sigma_{0}^{+}$ & $\hat{\infty}_{\infty}^{0}$ \\
\hline$\frac{n}{0}$ & 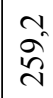 & $\frac{n}{n}$ & $\frac{0}{6}$ & î & ָิ & $\begin{array}{l}\infty \\
\stackrel{0}{0} \\
\text { in }\end{array}$ & $\tilde{\tilde{n}}$ & $\begin{array}{l}\infty \\
\text { î } \\
\text { î. }\end{array}$ & $\begin{array}{l}\vec{d} \\
\vec{v}\end{array}$ & $\frac{\vec{a}}{2}$ & $\begin{array}{l}\stackrel{\nabla}{a} \\
\stackrel{\sim}{\sim}\end{array}$ & $\overbrace{0}^{+}$ & 요 & $\hat{D}_{0}^{\infty}$ & $\begin{array}{l}0 \\
\stackrel{0}{8} \\
\stackrel{2}{0}\end{array}$ & 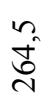 & 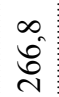 & 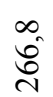 & है \\
\hline$=$ & \begin{tabular}{l}
0 \\
\multirow{0}{0}{}
\end{tabular} & ले & n & $\begin{array}{l}\infty \\
n \\
n\end{array}$ & $\begin{array}{l}n \\
2 \\
n \\
n\end{array}$ & $\begin{array}{l}0 \\
\stackrel{0}{n}\end{array}$ & $\overrightarrow{\tilde{n}}$ & $\begin{array}{l}\infty \\
\dot{m}\end{array}$ & $\begin{array}{l}\sim \\
\tilde{n}^{\prime}\end{array}$ & $\begin{array}{l}0 \\
0 \\
0\end{array}$ & 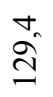 & $\stackrel{\infty}{m}$ & $\tilde{\sigma}$ & $\frac{N}{ \pm}$ & $\stackrel{n}{m}$ & $\begin{array}{l}\infty \\
\infty \\
n\end{array}$ & $\stackrel{n}{0}$ & $\begin{array}{l}m \\
\infty \\
\infty\end{array}$ & $\begin{array}{l}n \\
0 \\
n \\
n\end{array}$ \\
\hline$\infty$ & $\frac{\gamma}{\exists}$ & مे & in & $\overrightarrow{\mathfrak{I}}$ & $\vec{\Xi}$ & $\hat{n}$ & $\vec{a}$ & $\stackrel{\infty}{\infty}$ & $\stackrel{n}{ \pm}$ & $\begin{array}{l}n \\
\omega_{2}\end{array}$ & $\hat{n}$ & $\hat{g}$ & $\begin{array}{l}\sigma_{0} \\
\stackrel{\infty}{\sim}\end{array}$ & $\stackrel{n}{9}$ & $\begin{array}{l}\infty \\
n \\
n\end{array}$ & $\begin{array}{l}\infty \\
\stackrel{-}{-}\end{array}$ & 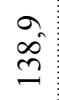 & $\begin{array}{l}\nabla_{\infty} \\
\infty \\
\sim\end{array}$ & $\begin{array}{l}0 \\
\text { J }\end{array}$ \\
\hline- & $\stackrel{2}{2}$ & 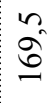 & $\begin{array}{l}0 \\
\text { i }\end{array}$ & $\stackrel{0}{ \pm}$ & $\underset{N}{N}$ & $\stackrel{n}{2}$ & $\stackrel{\infty}{\infty}$ & $\stackrel{\vartheta}{\hat{\nu}}$ & $\frac{0}{I}$ & $\overrightarrow{8}$ & $\begin{array}{l}\hat{\sigma} \\
\infty \\
\infty\end{array}$ & $\vec{\Omega}$ & $\stackrel{+}{\circ}$ & $\frac{\infty}{\infty}$ & $\stackrel{\circ}{\stackrel{0}{I}}$ & $\stackrel{\sqrt{\infty}}{\underline{\Delta}}$ & $\vec{x}$ & $\stackrel{m}{\infty}$ & 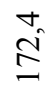 \\
\hline نَّ & 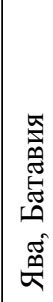 & 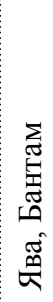 & 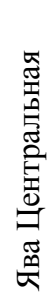 & 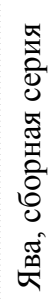 & 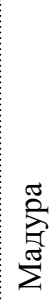 & 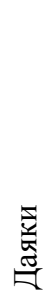 & 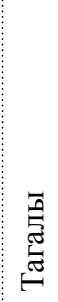 & 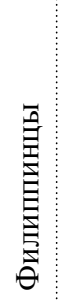 & $\frac{\pi}{2}$ & 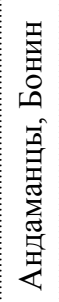 & 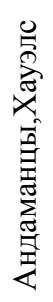 & 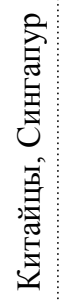 & 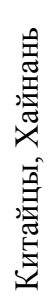 & 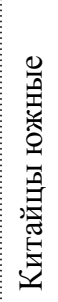 & 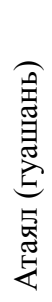 & 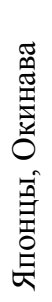 & 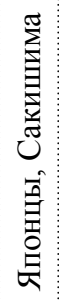 & $\begin{array}{l}0 \\
0 \\
0 \\
0 \\
\text { 量 } \\
\text { 员 }\end{array}$ & 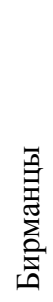 \\
\hline
\end{tabular}




\begin{tabular}{|c|c|c|c|c|c|c|c|c|c|c|c|c|c|c|c|c|c|c|c|c|}
\hline U & $\mathscr{0}_{\infty}^{0}$ & $\vec{\infty}$ & 2 & $\begin{array}{l}0 \\
\stackrel{2}{2}\end{array}$ & $\vec{r}$ & $\infty^{n}$ & $\begin{array}{l}\infty \\
2\end{array}$ & $\stackrel{2}{\stackrel{2}{2}}$ & $\begin{array}{l}\infty \\
\stackrel{0}{\circ}\end{array}$ & $\overbrace{0}^{n}$ & $\begin{array}{l}\circ \\
\stackrel{N}{N}\end{array}$ & $\begin{array}{l}\dot{ }_{n} \\
\stackrel{n}{n}\end{array}$ & $\hat{ल}$ & లు & $\underset{\infty}{\stackrel{n}{\infty}}$ & $\stackrel{m}{m}$ & $\stackrel{9}{f}$ & 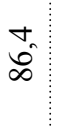 & ले & $\stackrel{n}{\simeq}$ \\
\hline 5 & $\begin{array}{l}\infty \\
\infty_{\infty}\end{array}$ & $\begin{array}{l}\infty \\
\infty \\
\infty\end{array}$ & $\stackrel{\infty}{\infty}_{\infty}$ & $\begin{array}{l}\infty \\
\infty \\
\infty\end{array}$ & $\begin{array}{l}\text { के } \\
\text { के }\end{array}$ & $\varnothing_{\infty}^{1}$ & $\frac{\nabla_{n}}{\infty}$ & $\frac{2}{\infty}$ & $\begin{array}{l}\stackrel{\partial}{\infty} \\
\dot{\infty}\end{array}$ & $\frac{n}{\infty}$ & $\frac{n}{\infty}$ & $\begin{array}{l}\infty \\
\dot{\infty}^{+}\end{array}$ & $\overrightarrow{a i n}$ & $\approx$ & \begin{tabular}{l}
$\hat{1}$ \\
\multirow{\infty}{\infty}{}
\end{tabular} & $\sigma_{-1}^{6}$ & $\stackrel{\text { ڤ }}{-1}$ & $\begin{array}{l}\hat{\infty} \\
\infty \\
\infty\end{array}$ & $\frac{\nabla_{\infty}}{\infty}$ & $\infty^{\infty}$ \\
\hline$\frac{1}{\lambda}$ & $\stackrel{+}{\circ}$ & $\hat{\infty}$ & $\infty$ & $\vec{\infty}$ & $\frac{n}{\infty}$ & 0 & $\frac{\sigma}{\sigma}$ & مे & $\stackrel{\sim}{\dot{\infty}}$ & $\hat{\infty}$ & $\begin{array}{l}0 \\
0 \\
\infty\end{array}$ & ल) & $\stackrel{m}{\infty}^{\infty}$ & $\approx$ & $\begin{array}{l}\hat{b} \\
\infty \\
\infty\end{array}$ & $\begin{array}{l}8 \\
\dot{0}\end{array}$ & $\frac{\sqrt{2}}{\sigma^{2}}$ & $\begin{array}{l}0 \\
\dot{A}\end{array}$ & $\hat{\infty}$ & $\stackrel{m}{\sim}$ \\
\hline$\sqrt{2}$ & $\hat{n}$ & $\stackrel{m}{m}$ & $\begin{array}{l}\dot{\sigma}^{2} \\
\stackrel{2}{ }\end{array}$ & $\begin{array}{l}\stackrel{\sim}{\tilde{m}} \\
\stackrel{\tilde{m}}{\sim}\end{array}$ & $\begin{array}{l}\stackrel{0}{0} \\
\stackrel{n}{=}\end{array}$ & $\hat{\sigma}$ & $\begin{array}{l}0 \\
\dot{D} \\
-\end{array}$ & $\begin{array}{l}\sigma_{\infty} \\
\infty \\
-\end{array}$ & ๙ે & 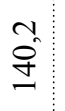 & $\begin{array}{l}\circ \\
\stackrel{n}{-}\end{array}$ & $\begin{array}{l}\vec{\Xi} \\
\vec{\Xi}\end{array}$ & $\begin{array}{l}\infty \\
\mathbb{J}^{\prime}\end{array}$ & ๗) & $\frac{2}{m}$ & 8 & $\begin{array}{l}\hat{n} \\
\forall\end{array}$ & $\begin{array}{l}\infty \\
\stackrel{ \pm}{ \pm}\end{array}$ & त̂ & $\overrightarrow{\tilde{a}}$ \\
\hline 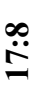 & $\stackrel{\forall}{a}$ & $\stackrel{n}{8}$ & $\hat{a}^{n}$ & $\stackrel{\infty}{\infty}$ & $\stackrel{\sim}{\infty}$ & $\vec{\sigma}$ & $\begin{array}{c}\hat{n} \\
\hat{\sigma}\end{array}$ & $\hat{\sigma}^{n}$ & $\stackrel{n}{8}$ & $\begin{array}{l}\infty \\
\stackrel{0}{0}\end{array}$ & $\begin{array}{l}\infty \\
\tilde{0}\end{array}$ & $\stackrel{m}{\sigma}$ & $\begin{array}{l}\nabla_{0} \\
\sigma^{\infty}\end{array}$ & $\approx$ & $\begin{array}{l}\infty \\
\text { N } \\
\infty \\
\alpha\end{array}$ & $\bar{m}$ & $\frac{0}{m^{\prime}}$ & $\begin{array}{l}\infty \\
\hat{\Xi}^{*}\end{array}$ & $\hat{n}$ & $\stackrel{n}{\simeq}$ \\
\hline$\ddot{\Xi}$ & $\stackrel{\infty}{\stackrel{n}{r}}$ & in & $\stackrel{+}{\stackrel{+}{*}}$ & $\stackrel{0}{\circ}$ & $\ddot{n}$ & $\begin{array}{l}0 \\
\sim\end{array}$ & $\stackrel{\infty}{i}$ & $\stackrel{n}{n}$ & $\stackrel{\circ}{i}$ & $\vec{n}$ & $\stackrel{\nabla_{n}}{\sim}$ & $\stackrel{0}{i}$ & $\begin{array}{l}0 \\
0 \\
0\end{array}$ & $\approx$ & $\vec{n}$ & $\frac{N}{i}$ & $\begin{array}{l}n \\
m\end{array}$ & $\tilde{\gamma}^{2}$ & $\begin{array}{l}0 \\
\infty \\
\infty\end{array}$ & $\stackrel{m}{0}^{2}$ \\
\hline $\bar{\infty}$ & $\begin{array}{l}0 \\
\stackrel{1}{*}\end{array}$ & $\stackrel{n}{n}$ & $\stackrel{و}{\stackrel{f}{*}}$ & $\stackrel{m}{n}$ & $\stackrel{m}{n}$ & $\stackrel{\infty}{i}$ & $\stackrel{\infty}{\stackrel{\infty}{\approx}}$ & $\vec{\nabla}$ & $\vec{\nabla}$ & $\begin{array}{l}\infty \\
\hat{b}^{n}\end{array}$ & $\stackrel{\infty}{\stackrel{\infty}{R}}$ & $\stackrel{0}{\circ}$ & $\hat{\hat{b}}$ & $\approx$ & $\begin{array}{l}\stackrel{2}{2} \\
\stackrel{2}{2}\end{array}$ & $\vec{F}$ & $\vec{n}$ & $\begin{array}{c}0 \\
\dot{\infty}\end{array}$ & $\hat{g}$ & $\stackrel{m}{ \pm}$ \\
\hline$\frac{\infty}{0}$ & $\hat{\tilde{d}}$ & $\begin{array}{l}\vec{\infty} \\
\curvearrowleft\end{array}$ & $\overrightarrow{\mathrm{n}}$ & $\overrightarrow{\vec{D}}$ & $\frac{n}{n}$ & $\begin{array}{l}0 \\
\text { d }\end{array}$ & $\vec{\sigma}_{\vec{v}}$ & $\begin{array}{l}m \\
\hat{D}\end{array}$ & $\begin{array}{l}\overrightarrow{8} \\
\stackrel{D}{2}\end{array}$ & $\begin{array}{l}\tilde{n}^{2} \\
\text { ते }\end{array}$ & $\begin{array}{l}\hat{\sigma} \\
\hat{\sigma}\end{array}$ & $\begin{array}{l}m_{1} \\
\infty \\
\infty^{2}\end{array}$ & $\begin{array}{l}0 \\
\hat{\sigma} \\
\sim\end{array}$ & $\approx$ & 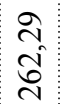 & $\begin{array}{l}\infty \\
\stackrel{+}{+}\end{array}$ & $\stackrel{0}{n}$ & $\begin{array}{l}\infty \\
\hat{D}^{\prime}\end{array}$ & $\vec{a}$ & $\hat{\infty}$ \\
\hline I & $\begin{array}{l}n \\
\text { nิ }\end{array}$ & ले & $\begin{array}{l}n \\
\stackrel{2}{n}\end{array}$ & $\begin{array}{l}\overbrace{0} \\
\stackrel{\overbrace{}}{n}\end{array}$ & $\begin{array}{l}\overrightarrow{0}_{0} \\
\stackrel{\oplus}{=}\end{array}$ & $\begin{array}{l}n \\
n \\
n\end{array}$ & $\begin{array}{l}0 \\
\stackrel{2}{1}\end{array}$ & $\begin{array}{l}n \\
\tilde{n}\end{array}$ & $\frac{N}{n}$ & $\stackrel{\sim}{n}$ & $\begin{array}{l}0 \\
\tilde{0}^{2} \\
n\end{array}$ & 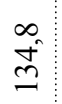 & $\begin{array}{l}\infty \\
\stackrel{0}{0} \\
\stackrel{n}{n}\end{array}$ & $\approx$ & $\begin{array}{l}\dot{0} \\
\dot{0} \\
\stackrel{+}{-}\end{array}$ & $\frac{n}{n}$ & $\begin{array}{l}\Delta \\
0 \\
i\end{array}$ & $\frac{N_{1}}{\exists}$ & $\begin{array}{l}\text { Oे } \\
\text { ป̀ }\end{array}$ & $\underline{\simeq}$ \\
\hline$\infty$ & mे & $\hat{\tilde{a}}$ & $\begin{array}{l}m \\
n \\
n\end{array}$ & $\frac{n}{n}$ & $\begin{array}{l}0 \\
m\end{array}$ & $\stackrel{\infty}{n}^{\infty}$ & $\begin{array}{l}\hat{\sigma}^{\prime} \\
\hat{m}\end{array}$ & $\begin{array}{l}\infty \\
\infty \\
n\end{array}$ & $\frac{0}{m}$ & ๙̃ & $\stackrel{\tilde{m}}{\tilde{m}}$ & $\begin{array}{l}\infty \\
\tilde{n} \\
\end{array}$ & $\begin{array}{l}0 \\
\stackrel{n}{n}\end{array}$ & $\approx$ & $\frac{\stackrel{N}{2}}{m}$ & $\stackrel{\stackrel{\sim}{2}}{\sim}$ & $\begin{array}{l}\text { aे } \\
\text { m }\end{array}$ & $\begin{array}{l}0 \\
\stackrel{f}{ \pm}\end{array}$ & ते & $\stackrel{\infty}{ \pm}$ \\
\hline- & $\stackrel{\partial}{\Omega}$ & $\begin{array}{l}\infty \\
\stackrel{0}{2}\end{array}$ & $\underset{\infty}{\infty}$ & $\begin{array}{l}0 \\
\stackrel{2}{I}\end{array}$ & $\stackrel{ }{\approx}$ & $\infty_{\infty}^{\infty}$ & $\begin{array}{l}\infty \\
\Omega^{2}\end{array}$ & $\vec{\infty}$ & $\begin{array}{l}\sigma \\
\infty \\
\infty \\
-1\end{array}$ & $\begin{array}{l}\sim \\
\infty\end{array}$ & $\begin{array}{l}\text { గ̌ } \\
\infty\end{array}$ & $\begin{array}{l}\stackrel{0}{\Omega} \\
\stackrel{8}{2}\end{array}$ & $\hat{\sigma}^{\circ}$ & $\approx$ & $\frac{\infty}{\infty}$ & $\begin{array}{l}\infty \\
\text { in }\end{array}$ & $\begin{array}{l}0 \\
\text { m. } \\
m\end{array}$ & $\stackrel{\hat{\sigma}}{\hat{\sigma}}$ & जी: & $\stackrel{\infty}{\stackrel{\sim}{\sim}}$ \\
\hline$\underline{\Sigma}$ & 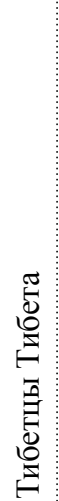 & 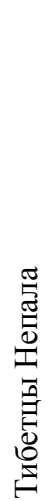 & 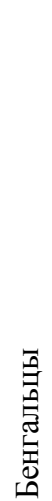 & 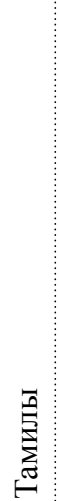 & 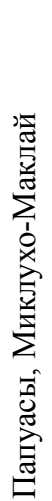 & 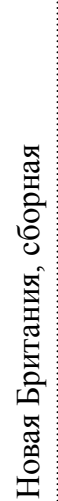 & 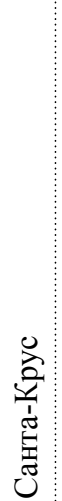 & $\begin{array}{c}\text { 哥 } \\
\\
\\
\end{array}$ & $\mid \begin{array}{c}2 \\
\vdots \\
0 \\
0 \\
\sum_{2}^{2} \\
\dot{0}\end{array}$ & 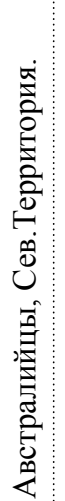 & 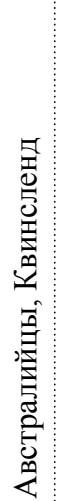 & 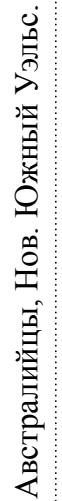 & 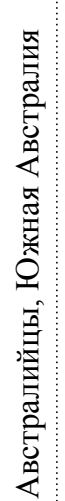 & 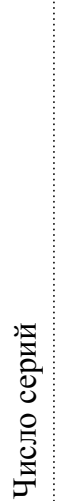 & 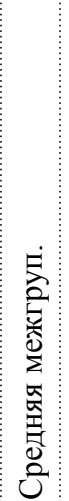 & 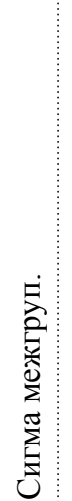 & 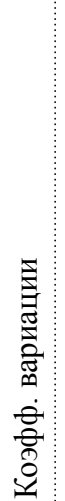 & 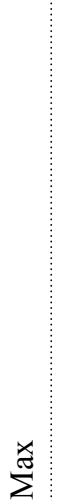 & $\stackrel{\Xi}{\Sigma}$ & $\sum_{\substack{1 \\
⿱ 亠 凶 \\
\Sigma}}^{\Xi}$ \\
\hline
\end{tabular}


Общая абсолютная величина черепной коробки (признак ОРВ) варьирует здесь значительно - от 251,1 (у андаманцев серии Бонина) до 269,8 (в серии южных китайцев). Среди основных диаметров черепной коробки наиболее изменчивой оказалась величина продольного диаметра, наименее изменчивой - высотного диаметра. Межгрупповая дисперсия (сигма) у первого признака оказалась в два с лишним раза больше, чем у второго. Среди парных индексов формы $(8: 1,17: 1,17: 8)$ наиболее вариабельным оказался черепной указатель. Он варьирует от 84,0 (выраженная брахикрания) у аэта Филиппин, видимо сильно смешанных с другими филиппинцами, до 69,7 (ультрадолихокрания) у австралийцев Южной Австралии. Заметно менее вариабельными оказались высотно-продольный и высотно-поперечный указатели. Среди тройных индексов (УД, УБ, УГ) исключительно сильно варьирует указатель долихоидности - от 122,7 у аэта до 144,8 у австралийцев Южной Австралии. Коэффициент межгрупповой вариации этого признака равен 4,57. Исключительно мало варьирует указатель гипсиоидности - от 88,9 у яванцев Батавии до 81,4 у меланезийцев островов Санта-Крус. Здесь коэффициент межгрупповой вариации равен 1,89). Вариабельность этого признака почти в 2,5 раза меньше, чем у указателя долихоидности.

Итак, краниосерии изучаемого региона показывают исключительную разнородность, как по общему размеру черепа, так и по его форме. При этом, разнообразие в наибольшей мере задаётся величиной продольного диаметра черепа и индексами, связанными с ним. Менее всего влияет на это разнообразие высотный диаметр черепной коробки и соответствующий ему указатель гипсиоидности (УГ). Признаки, связанные с величиной поперечного диаметра, здесь занимают промежуточное значение.

Далее была построена дендрограмма таксономических расстояний между изучаемыми краниосериями по всем 11 признакам черепной коробки (рис. 1).

Здесь чётко выделяются три кластера. Дадим им нумерашию. начиная сверху -

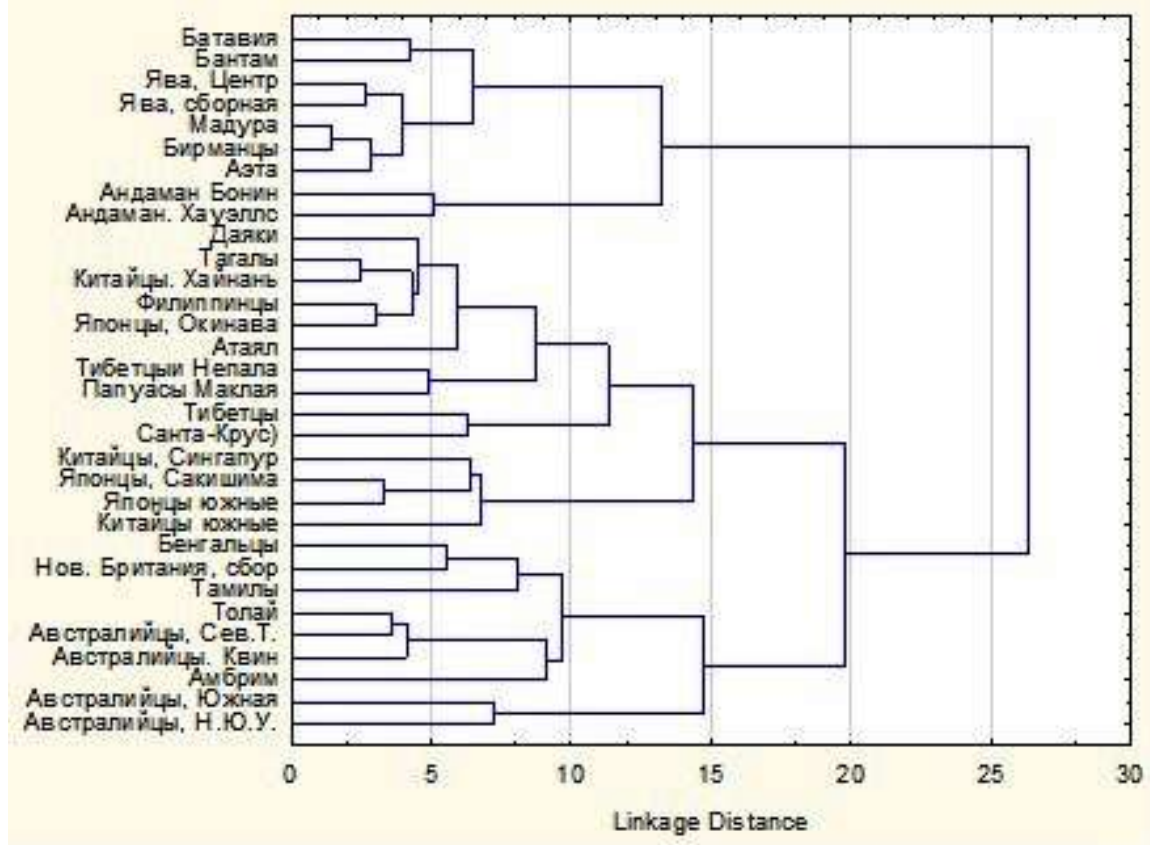

Рис. 1. Дендрограмма расстояний между изученными сериями по 11 признакам 
кластер № 1, № 2 и № 3. Первый кластер наиболее отдалён от двух других, более близких друг к другу. Обозначим краниосерии, объединяемые этими кластерами.

1 кластер: яванцы Батавии (столица Нидерландской Индонезии - ныне Джакарта), яванцы Бантама (крайне западная провинция Явы), яванцы Центральной Явы, сборная серия яванцев (в основном с восточной Явы), мадурцы (яванцы о. Мадура), аэта Филиппинских островов, бирманцы Индокитая и андаманцы (серии Бонина и Хауэллса). Краниосерии андаманцев образуют малый субкластер 1-го кластера.

2 кластер: даяки Калимантана, китайцы Сингапура, китайцы о. Хайнань, китайцы южные, сборная серия филиппинцев, тагалы (основной народ Филиппин), атаял (племя гаошань докитайского населения Тайваня), японцы о. Окинава, японцы островов Сакишма (архипелаг Рюкю), японцы юга Японии, тибетцы Непала, тибетцы Тибета. Кроме монголоидных групп в этот кластер попали: серия папуасов, собранная Миклухо-Маклаем и серия меланезийцев островов Санта-Крус. Серии этого кластера, сравнительно с 1-м кластером, покрывают значительно бо̀льшую территорию изучаемого ареала. Сюда попадают не только различные китайские, японские и тибетские серии, но и две серии островного мира за линией Уоллеса.

3 кластер составляют две наличные индийские серии - бенгальцы и тамилы; три серии меланезийцев: сборная меланезийцев Новой Британия, серия толай (племя северо-восточной части Новой Британии) и серия о. Амбрим; четыре серии австралийских аборигенов. Все они по нашей классификации принадлежат к панойкуменному краниотипу тропидов.

В следующей таблице представлены средние межгрупповые величины изучаемых признаков по трём выделенным кластерам отдельно. В скобках означена численность серий, входящих в соответствующий кластер.

Материалы данной таблицы иллюстрируют хорошо выраженную закономерность изменчивости величин изучаемых признаков. Практически все изученные признаки показывают изменение своей величины от первого кластера до третьего только в одном направлении: или увеличение или уменьшение. Действительно, величина продольного диаметра черепа, общая величина черепной коробки (ОРВ), высотно-поперечный указатель (17:8), указатель долихоидности (УД) монотонно увеличиваются от первого кластера к третьему. Величина поперечного диаметра черепа, черепной указатель (8:1), высотно-продольный указатель (17:1), указатель брахиоидности (УБ), степень сферичности черепа (CC) столь же монотонно уменьшаются от первого кластера к третьему.

Совершенно иначе ведёт здесь лишь один признак - высотный диаметр черепа. Закономерность изменчивости его от первого к четвёртому кластеру нарушается: высотный диаметр серий второго кластера больше, чем у первого кластера, а третьего кластера меньше. Указатель гипсиоидности (УГ) вроде бы соответствует нашей закономерности, но его величина очень слабо варьирует от кластера к кластеру (от 86,76 до 86,10), т.е. практически не меняется. Вообще, как явствует из таблицы 1 , величины этих двух признаков в изучаемом регионе наиболее стабильны, что указывает здесь на их особую значимость.

Далее рассмотрим различия изучаемых признаков между кластерными объединениями наших краниосерий и, что особенно важно, достоверность этих различий.

Данные по исследованным 11 краниологическим признакам мы для удобства разбили на две группы - признаки абсолютных размеров черепа: 1, 8, 17, ОРВ (таблица № 3a), и признаки формы черепной коробки - 8:1, 17:1, 17:8, УД, УБ, УГ, СС (таблица № 3б). 
줄

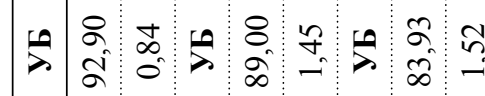

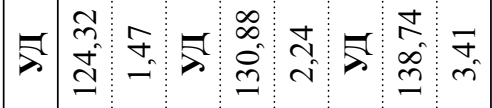

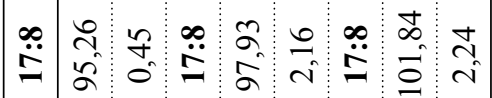

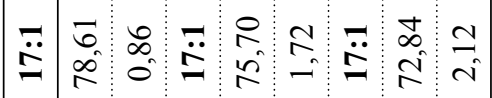

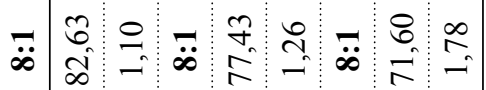

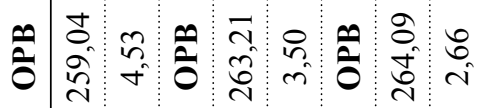

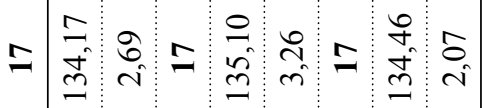

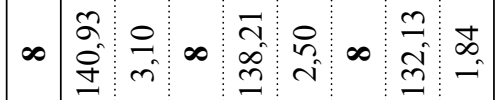

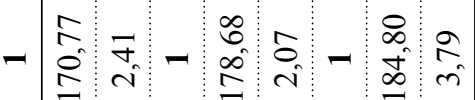

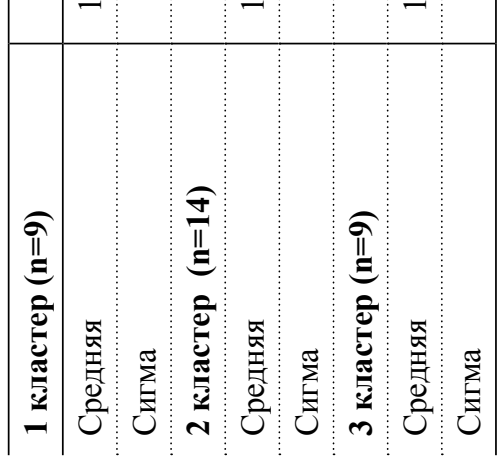

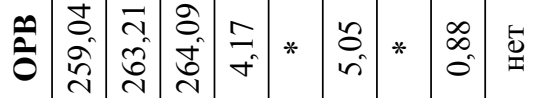

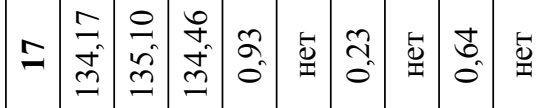

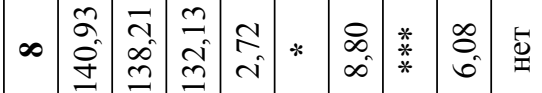
包

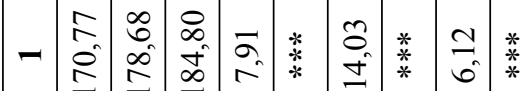

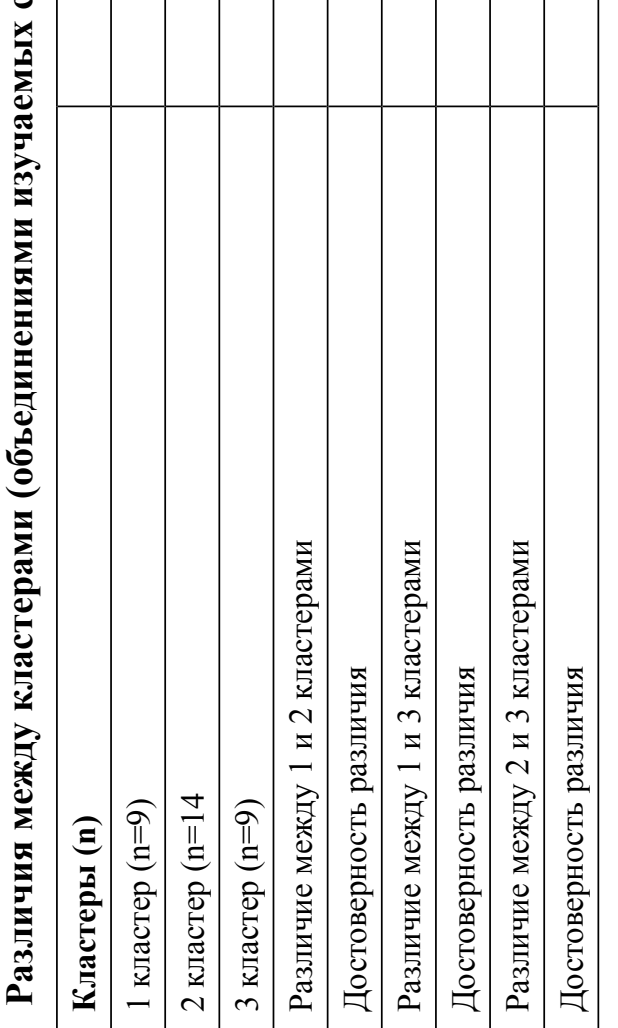


Из таблицы За видно, что величины продольного диаметра черепа достоверно отличаются между всеми тремя кластерами, причём на самом высоком статистическом уровне. Менее явственно проявляется различие между кластерами по величине поперечного диаметра черепа. Здесь различие между 2 и 3 кластерами по этому признаку статистически недостоверно. А величина высотного диаметра вообще не даёт никакого достоверного отличия между любой парой наших кластеров. Абсолютная величина черепной коробки также показывает монотонное увеличение от первого к третьему кластеру, что хорошо видно по численным значениям параметра ОРВ в каждом из фракций. Но при этом различие между 2 и 3 фракциями по этому признаку недостоверно.

Таблица $3 б$

Различия между кластерами (объединениями изучаемых серий) и достоверность различий признаков формы черепа.

\begin{tabular}{l|l|l|l|l|l|l|l}
\hline Кластеры (n) & $8: 1$ & $17: 1$ & $17: 8$ & УД & УБ & УГ & СС \\
\hline 1 кластер (n=9) & 82,63 & 78,61 & 95,26 & 124,32 & 92,90 & 86,76 & 85,12 \\
\hline 2 кластер (n=14) & 77,43 & 75,70 & 97,93 & 130,88 & 89,00 & 86,07 & 81,40 \\
\hline 3 кластер (n=9) & 71,60 & 72,84 & 101,84 & 138,74 & 83,93 & 86,10 & 77,10 \\
\hline Различие между 1 и 2 кластер. & 5,20 & 2,91 & 2,67 & 6,56 & 3,90 & 0,69 & 3,72 \\
\hline Достоверность различия & $* * *$ & $* * *$ & $* * *$ & $* * *$ & $* * *$ & нет & $* * *$ \\
\hline Различие между 1 и 3 кластер. & 11,06 & 5,77 & 6,58 & 14,42 & 8,97 & 0,66 & 8,02 \\
\hline Достоверность различия & $* * *$ & $* * *$ & $* * *$ & $* * *$ & $* * *$ & нет & $* * *$ \\
\hline Различие между 2 и 3 кластер & 5,83 & 2,86 & 3,91 & 7,86 & 5,07 & 0,03 & 4,30 \\
\hline Достоверность различия & $* * *$ & $* *$ & $* *$ & $* * *$ & $* * *$ & нет & $* * *$ \\
\hline
\end{tabular}

Примечание: Достоверность различия по t-критерию Стъюдента: * - 95\%, ** - 99\%, *** - 99,9\%

Из таблицы За видно, что величины продольного диаметра черепа достоверно отличаются между всеми тремя кластерами, причём на самом высоком статистическом уровне. Менее явственно проявляется различие между кластерами по величине поперечного диаметра черепа. Здесь различие между 2 и 3 кластерами по этому признаку статистически недостоверно. А величина высотного диаметра вообще не даёт никакого достоверного отличия между любой парой наших кластеров. Абсолютная величина черепной коробки также показывает монотонное увеличение от первого к третьему кластеру, что хорошо видно по численным значениям параметра ОРВ в каждом из фракций. Но при этом различие между 2 и 3 фракциями по этому признаку недостоверно.

Шесть признаков формы черепной коробки показывают строго монотонную изменчивость (или увеличение, или уменьшение) от первого к третьему кластеру. При этом различие между любой парой кластеров по этим признакам статистически достоверно на высоком уровне значимости. Однако указатель гипсиоидности (УГ), также, как и абсолютная величина высотного диаметра черепной коробки (см. таблицу № 3a), практически одинакова во всех трёх кластерах изученных нами краниосерий.

Степень сходства (или несходства) ростовых процессов черепной коробки в каждом из трёх кластеров, показывают значения коэффициентов межгрупповой корреляции величин диаметров черепа между собой и с общей ростовой величиной (OPB) в таблице 4. 


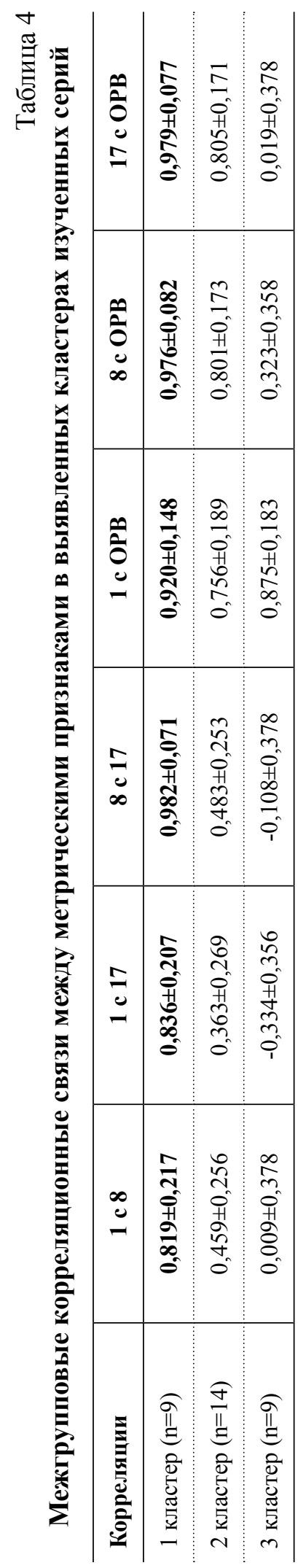

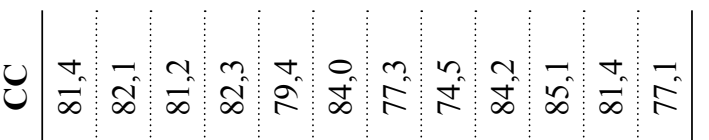

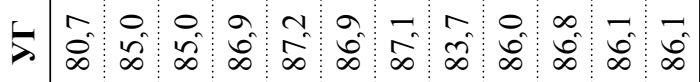

政

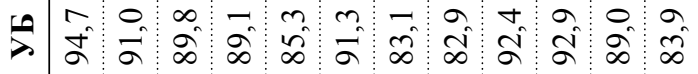

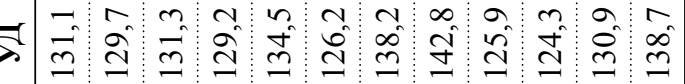

무

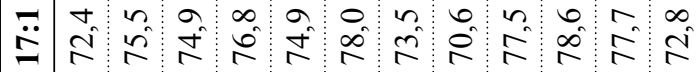

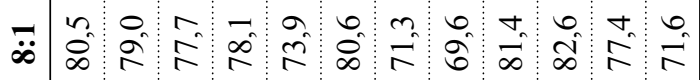

5

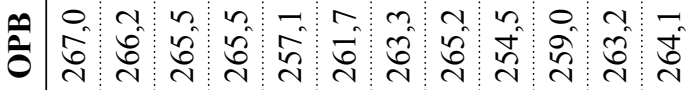

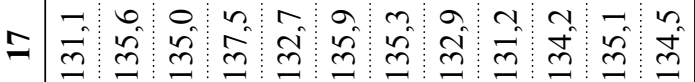

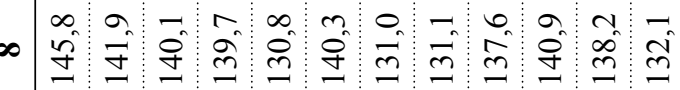

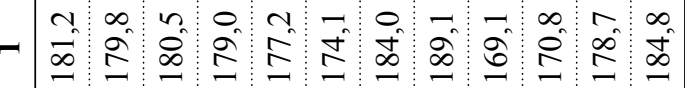

ह

兽

5ั

尔

胥

?

5

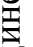

它

웅 
даром в дендрограмме (рис. 1) этот кластер отдалён от двух других, более близких между собой. Здесь корреляции между величинами основных диаметров черепа, а также их с общей его величиной в этом кластере имеют высокие и достоверные величины, что свидетельствует о сходных ростовых процессах в сериях этого кластера. Во 2-ом кластере эта закономерность заметно нарушается, что говорит о существенно различных типах ростовых процессов в краниосериях этого кластера. Что касается краниосерий, входящих в 3-ий кластер, то здесь очевидно мы находим изучаемые корреляционные связи в сильнейшей степени нарушенными. Это свидетельствует о значительном генетическом различии краниосерий, составляющих этот кластер. Действительно, в этот кластер входят расово разнородные краниосерии: две индийские, три меланезийские и четыре серии австралийских аборигенов. Хотя при этом все они входят в панойкуменный краниотип тропидов.

Далее в таблице 5 представлены краниологические характеристики трёх выделенных объединений (кластеров) 32-х серий, изученных нами по индивидуальным данным, на широком сравнительном фоне современных краниосерий значительной части Азии, Австралии, островного мира между Азией и Австралией и обеих Америк. При этом использовалась краниологическая классификационная схема авторов статьи (Пестряков, Григорьева 2004).

Здесь исходные данные по краниосериям восточных голарктидов (континентальные монголоиды) взяты из книги В.П. Алексеева и И.И. Гохмана (Алексеев, Гохман 1984), данные по индейцам Северной Америки из таблиц в книге Г.Ф. Дебеца «Антропологические исследования в Камчатской области» (Дебец 1951), в которой им приводятся среднегрупповые величины трёх основных диаметров черепа в краниосериях различных племён индейцев Северной Америки, опубликованных их исследователем А. Хрдличкой. Аналогичные данные по южноамериканским индейцам, взяты из работы Ньюмана (Newman 1949). Исходные данные по многочисленным сериям китайцев

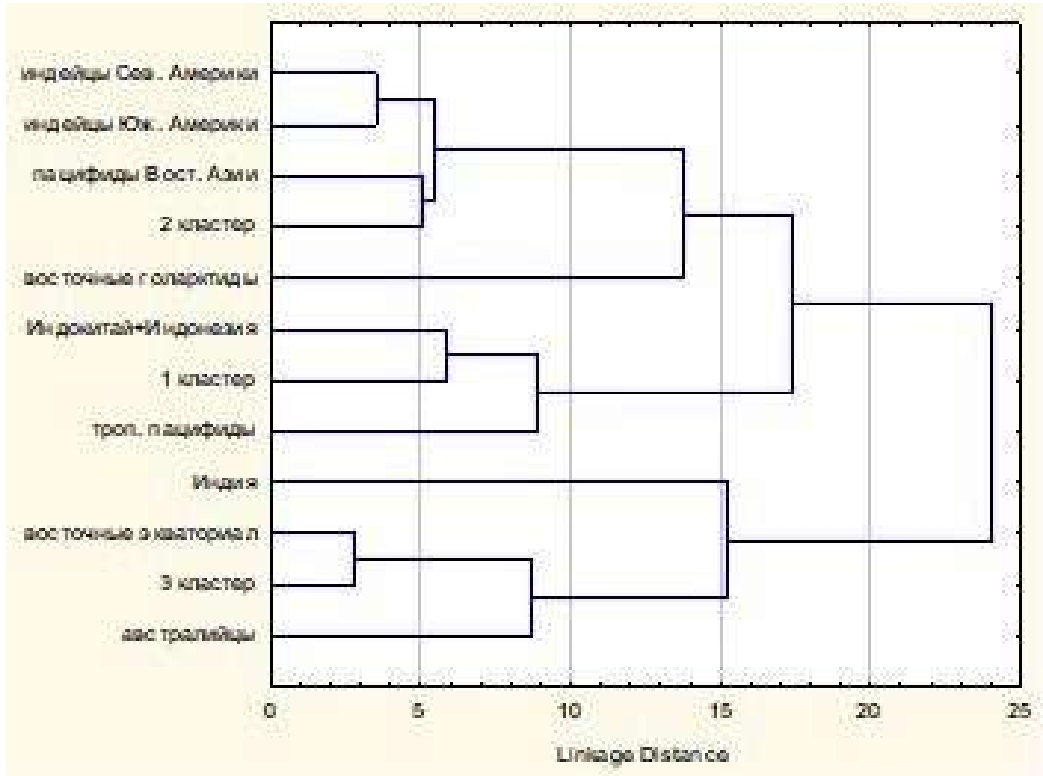

Рис. 2. Дендрограмма таксономических расстояний трёх кластеров с различными этно-территориальными объединениями краниосерий. 
и населения Индокитая и Индонезии взяты из таблиц приложения книги Н.Н. Чебоксарова «Этническая антропология Китая» (Чебоксаров 1982). Краниологические данные по сериям индийцев, папуасов и меланезийцев взяты из работы В.П. Алексеева (Alexejev, 1973). Данные по японским и австралийским краниосериями из более ранних наших работ (Пестряков, Григорьева 2011; Пестряков, Григорьева 2013).

В таблице названы краниологические объединения, в скобках численность серий, входящих в это объединение. Общая величина черепной коробки (OPB), а также все краниологические индексы в сравниваемых территориальных группах серий рассчитывались по среднегрупповым величинам трёх диаметров черепа, так как индивидуальных данных черепов для большинства этих серий в нашем распоряжении нет. Это снижает точность характеристик этих этно-территориальных краниологических объединений, но вряд ли серьёзно влияет на достоверность наших выводов.

Нижеследующая дендрограмма (рис.2) показывает таксономические расстояния трёх выделенных ранее кластеров изученных краниосерий на фоне этно-территориальных объединений краниосерий, представленных в таблице 5.

Из дендрограммы видно, что три кластера, выделенные при изучении 32 краниосерий изучаемой территории, отчётливо отличаются друг от друга и примыкают к различным этно-территориальным объединениям, представленным в таблице 5 .

2-ой кластер присоединяется к кластеру панойкуменного краниотипа пацифидов (краниосерии Восточной Азии, Северной и Южной Америки). При этом он таксономически наиболее близок к восточноазиатским пацифидам, частью которых он и является. Краниосерии 3-его кластера явно входят в другой панойкуменный краниотип - тип тропидов, где обнаруживают наибольшее сближение с сериями восточных экваториалов (папуасов и меланезийцев). В более ранней работе (Пестряков, Григорьева 2004) было отмечено, что для пацифидов наиболее характерна мезокранная форма черепа. Среднегрупповые величины черепного указателя всех 14 серий 2-го кластера варьируют в пределах мезокрании $(75,2-79,1)$. Для тропидов характерна долихокрания. Все девять краниосерий 3-его кластера долихокранны.

Краниосерии 1-ого выделенного кластера не обнаруживают сближения (сходства) с названными панойкуменными краниотипами. Не примыкают они также и к панойкуменному краниотипу голарктидов, представленному здесь объединением серий восточных голарктидов (континентальных монголоидов). По черепному указателю все девять серий этого кластера брахикранные. Они близки к обобщённой группе серий Индокитая и Индонезии, частью которой они видимо и являются. Последние также сильно отличаются как от пацифидов, так и от тропидов. К этому кластеру также присоединяются серии локального краниотипа тропических пацифидов. Следовательно, краниосерии подобного облика образуют самостоятельный краниотип, имеющий вполне определённый ареал своего возможного возникновения и современного доминирования - это территории Индокитая и Индонезии (бывшего субконтинента Сунда). Поэтому их логично называть сундиды.

В таблице 5 даны усреднённые краниологические характеристики трёх новых объединений этой дендрограммы (рис.2), по которым распределились те три кластера, на которые разбились 32 изученные нами краниосерии.

Занимая территорию географически промежуточную между ареалами распространения классических пацифидов и восточных тропидов, которые наиболее контрастно выражают особенности тропидов, сундиды по своим особенностям не демонстриру- 
ют промежуточной краниологической характеристики между ними. Действительно, общая величина черепной коробки у них здесь минимальна. Для сундидов типична брахикрания, для пацифидов - мезокрания, для тропидов - долихокрания. Череп у сундидов более коротктй (абсолютно и относительно) и более широкий (абсолютно и относительно). И как следствие этого, степень сферичности черепной коробки у них здесь максимальна (параметр $\mathrm{CC}=84,0$ ). Величина этого последнего признака особенно показательна, т.к. указывает на вектор эволюционной направленности изменения формы мозгового черепа человека. Чем сферичнее по форме череп, тем экономнее расходуется костный материал для получения наибольшего объёма мозговой полости, этого важнейшего морфологического признака рода Ното.

Таблица 5

Характеристики трёх краниологических объъдинений, в которые входят также изученные нами краниосерии

\begin{tabular}{|c|c|c|c|c|c|c|c|c|c|c|c|}
\hline & 1 & 8 & 17 & OPB & $8: 1$ & $17: 1$ & $17: 8$ & уд & УБ & $\mathbf{У} \Gamma$ & $\mathrm{CC}$ \\
\hline 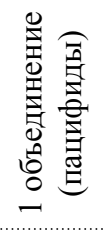 & 179,5 & 139,2 & 136,0 & 264,0 & 76,8 & 75,5 & 98,5 & 131,4 & 88,4 & 86,2 & 81,1 \\
\hline 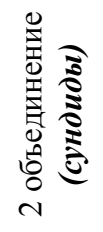 & 171,3 & 139,6 & 133,8 & 259,5 & 80,9 & 77,8 & 96,2 & 126,2 & 91,7 & 86,6 & 84,0 \\
\hline 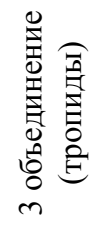 & 183,8 & 131,3 & 133,9 & 264,7 & 70,7 & 72,4 & 102,5 & 140,0 & 83,1 & 85,8 & 76,3 \\
\hline
\end{tabular}

Среди сундидов встречается краниосерии, имеющие такие же параметры формы черепной коробки, но значительно меньшую её абсолютную величину (признак ОРВ). В нашей ранней работе, посвящённой краниологической классификации (Пестряков, Григорьева 2004) он был назван локальным краниотипом тропических пацифидов. Его классическими представителями являются андаманцы, в меньшей степени (из-за метисации их с собственно филиппинцами) аэта Филиппинских островов, а также некоторые группы западных меланезийцев. Эти малочисленные группы (популяции), рассеянные на обширных пространствах изучаемой здесь территории, вкраплены в значительно более многолюдный массив населения, имеющего другую краниологическую или расовую характеристику.

Среди большинства изученных краниосерий встречаются представители этнических групп, имеющих сравнительно малую абсолютную величину черепной коробки. Таковы пигмеи Центральной Африки, ведды Цейлона (Шри Ланки) и представленные здесь андаманцы и аэта. Для всех подобных этносов характерен 
присваивающий тип хозяйства в условиях тропического дождевого леса, по крайней мере, так было до недавнего времени. По форме черепной коробки они заметно отличаются друг от друга, но довольно сходны со своими более крупноголовыми (и более рослыми) соседями, ведущих хозяйство производящего типа, с которыми они зачастую смешиваются. Для пигмеев обычно такими соседями являются негроиды банту, для веддов Цейлона - сингалы, для аэта, как уже отмечалось, филиппинцы (тагалы и др.). Андаманцы - жители довольно изолированного архипелага, вероятно, являются выраженным изолятом.

Выделение краниотипа сундидов позволяет серьёзно изменить краниологические подразделения монголоидной расы. Еще в 1951 году Н.Н. Чебоксаров разделил монголоидную расу на два различных краниотипа - континентальные и тихоокеанские монголоиды (Чебоксаров 1951). Согласно нашей краниологической классификации современного населения, континентальные монголоиды являются голарктидами (вместе с основной массой европеоидов), а тихоокеанские монголоиды пацифидами (вместе с основной массой американоидов). Результатом настоящей работы является выделение южных монголоидов (большинство населения Индокитая и Индонезии) в самостоятельный краниотип сундидов, отличный от всех трёх панойкуменных краниотипов современного населения Земли: тропидов, пацифидов и голарктидов.

В дальнейшем следует уточнить характеристики этого краниотипа, границы зоны его распространения, а также наметить его метисные варианты с иными краниологическими подразделениями.

\section{Основные выводы}

Изучаемая территория, соединяющая юго-восточную Азию с Австралией и Западной Океанией, исключительно разнородна в антропологическом отношении. Здесь наблюдается сложная мозаика взаимодействия этнических групп южных монголоидов, восточных монголоидов, меланезийцев (восточных экваториалов), австралоидов и малочисленных, экзотических по культуре и антропологическому типу популяций, нередко называемых негриллями (андаманцы, аэта и др.).

Изучение по индивидуальным данным черепов 32-х краниологических серий этой территории выявили на ней три существенно различных краниотипа. Два из них уже известны и удовлетворительно охарактеризованы. Это классические пацифиды, к которым отнесены изученные нами серии даяков, филиппинцев, китайцев, японцев и тибетцев. Второй из них тропиды. Здесь это - индийские краниосерии, меланезийцы и австралийцы.

Однако третий выявленный краниотип - сундиды, выделяется и характеризуется впервые. Для них характерны черепа малого размера, укороченные и довольно широкие по форме. Череп у них по форме наиболее сферичный из всех современных краниотипов. Зона их наибольшего распространения Индокитай и большая часть Индонезии.

Таким образом, большую монголоидную расу в краниологическом (мозговой череп) отношении теперь можно разделять на три основных краниотипа: континентальные монголоиды, тихоокеанские монголоиды и сундиды (южные монголоиды). 


\section{Научная литература}

Алексеев В.П. Материалы по краниологии Новой Гвинеи, Зондских и Молуккских островов, Малайского полуострова // Культура народов Австралии и Океании. Сборник Музея антропологии т этнографии XXX. Л.: Наука, Ленинградское отделение, 1974. С. 187-236.

Алексеев В.П. К краниологии бенгальцев. // Новые материалы к антропологии Западной Индии: Результаты советско- индийских исследований / АН СССР, Ин-т этнографии им. Н.Н. Миклухо-Маклая. М.: Наука, 1982. С. 301-312.

Алексеев В.П., Гохман И.И. Антропология азиатской части СССР. М.: Наука, 1984.

Дебеи Г.Ф. Антропологические исследования в Камчатской области. Труды Северо-восточной экспедиции. М.: Изд-во Академии наук СССР, 1951. Т. І.

Пестряков А.П., Григорьева О.М. Краниологическая дифференциация современного населения. // Расы и народы. Ежегодник. М.: Наука, 2004. № 30. С. 86-131.

Пестряков А.П., Григорьева О.М. Некоторые данные по краниологии населения Японских островов. // Вестник антропологии. Научный альманах. М., 2011. Вып. 20. С.23-35.

Пестряков А.П., Григорьева О.М. Австралийские аборигены на краниологическом фоне населения Южной и Юго-восточной Азии и Западной Океании. //Вестник Московского университета. М.: Изд-во Московского университета, 2013. Серия ХХІІІ. Антропология. № 2. C. 17-33.

Чебоксаров Н.Н. Основные принципы антропологической классификации // ТИЭ (нов. сер.). М.- Л., 1951. T. XVI.

Чебоксаров Н.Н. Этническая антропология Китая. М.: Наука. Главная редакция восточной литературы, 1882.

Alexejev V. P. Craniological material from new Guinea, Indonesia and the Malayan Peninsula // Anthropologie. Moravske Muzeum - Ustav Anthropos. Brno, 1973. Pp. 201-248.

Dodo Yukio at all. Metric Data of Ryukyunan Crania. Anthropological Sciense, 2001. No. 109 (2). Pp. 182-190.

Bonin, Gerhard von. Beitrag zur Kraniologie von Ost-Asitn. Biometrika, 1931. Vol. 21. No.1/2. Pp. 52-113.

Hambly Wielfred D. Craniology of Ambrim Island. Fieldiana: Anthropology, Chicago, 1946. Vol.37. No. 1. P. 1-46

Harrower Gordon. A Study of the Hakian and Tamil Scull. Singapore, 1925, Pp. 1-31. Appendix.

Howells W.W. Who is Who in Skulls. Ethnic Identification of Crania from Measurements. Papers of the Peabody Museum of Archaeology and Ethnology. Cambridge, Mass.: Peabody Museum. 1995. Vol. 82. Pp. 108.

Howells W.W. Craniometric data set. http:// web.utk.edu/ - auerbach/HOWL.htm.

Hrdlicka A. Catalogue of human crania in the United States national museum collectilns. Procceedings of the of the United States national museum. Washington, 1928. Vol. 71.

Morant G. M. A Study of certain series including the Nepalese and Tibetan series in the British Museum (Natural History). Biometrika, 1924. Vol.16. No. 1/2 (May 1924). Pp. 1-105.

Newman M.T. The Sequence of Indian Physical Types in South America // Papers on the Physical Anthropology of the American Indian. New York, 1949. Vol. 21. P. 69-97.

Tidesley M.L. A first Study of Burmese Skull. Biometrika, 1921. Vol. 13. No. 2/3 (Jul. 1921). Pp. 176-262.

Pestriakov Aleksander P., Grigoryeva Olga M., Pelenitsyna Yulia V.

DOI: $10.33876 / 2311-0546 / 2021-53-1 / 166-182$

\section{Between Asia and Australia (neurocranial diversity of the modern population of Southeast Asia)}

This work continues the studies devoted to the worldwide classification of modern humans 
by the neurocranial skull. Cranial dimensions of population of vast territories of Southeast Asia, Australia and the islands between these continents were studied. The study was based on a comparative analysis of individual data from male skulls from 32 samples, taken from published works of anthropologists who studied this region. The dendrogram of the distances between these 32 samples, based on 11 measures of the size and shape of the skull, is formed by three distinctive clusters. Samples from the first cluster are characterized as typical for the Pacifid craniotype (mesocranial skulls). Samples from the second cluster belong to the East Tropid craniotype (dolichocranial skulls). Samples from the third cluster differ both from the two craniotypes mentioned above and another craniotype, called Golarktids (this type is not presented in the studied area). We called this last cluster "Sundids", because they are mainly localized in the Sunda subcontinent. This area was formed during the sea regression during the Pleistocene, when the shelf seas of Southeast Asia and Indonesia turned into land, part of a single Eurasian continent. In this sample, the skulls are small and brachycranial. A large part of Indochinese and Indonesian crania can be attributed to this craniotype. Thus, the great Mongoloid race can be divided into three different craniological types: continental Mongoloids (Golarktids), Pacific Mongoloids (Pacifids), and southern Mongoloids (Sundids).

Key words: skull, cranioseries, craniotype, Sundids.

For Citation: Pestriakov, A.P.. O.M. Grigoryeva and Y.V. Pelenitsyna. 2021. Between Asia and Australia (neurocranial diversity of the modern population of Southeast Asia). Herald of Anthropology (Vestnik Antropologii) 1 (53): 166-182.

Pestriakov Altksander P. - PhD in hist., Institute of Ethnology and Anthropology, RAS (Moscow, Leninsky Pr. 32-a). E-mail:labrecon@yandex.ru

Grigorieva Olga M. - PhD in biol., Institute of Ethnology and Anthropology, RAS (Moscow, Leninsky Pr.32-a).E-mail:labrecon@yandex.ru

Pelenitsyna Yulia V. - student of M.V. Lomonosov Moscow state University. (Moscow, Russia). E-mail: j.pelenitsyna@gmail

The research is published as part of the Research Plan of the Institute of Ethnology and Anthropology (Russian Academy of Sciences, Moscow), "The evolutionary continuum of the genus Homo", Subtopic "Anthropology of Ancient and Modern Populations".

\section{References}

Alexejev, V. P. 1973. Craniological material from new Guinea, Indonesia and the Malayan Peninsula // Anthropologie. Moravske Muzeum - Ustav Anthropos, 201-248. Brno.

Alekseev, V.P. 1974. Materialy po kraniologii Novoj Gvinei, Zondskih i Molukkskih ostrovov, Malajskogo poluostrova [Materials on the craniology of New Guinea, the Sunda and Moluccas Islands, and the Malay Peninsula].//Kul'tura narodov Avstralii i Okeanii. Sbornik

Muzeya antropologii i etnografi, XXX, 187-236. Leningrad: Nauka, Leningradskoe otdelenie.

Alekseev, V.P. 1982. K kraniologii bengal'cev [To the craniology of Bengalis]. Novye materialy $k$ antropologii Zapadnoj Indii: Rezul'taty sov. Issledovanij, 301-312. Moscow: Nauka.

Alekseev, V.P., and Gohman I.I. 1984. Antropologiya aziatskoj chasti SSSR [Anthropology of the Asian part of the USSR]. Moscow: Nauka.

Bonin, Gerhard von. Beitrag zur Kraniologie von Ost-Asitn. 1931. Biometrika 21 (1/2): 52-113.

Cheboksarov, N.N. 1951. Osnovnye principy antropologicheskoj klassifikacii [Basic principles of anthropological classification]. TIE (nov. ser.), XVI. Moscow; Leningrad.

Cheboksarov, N.N. 1882. Etnicheskaya antropologiya Kitaya [Ethnic Anthropology of China]. Moscow: Nauka, Glavnaya redakciya vostochnoj literatury.

Debec, G.F. 1951. Antropologicheskie issledovaniya v Kamchatskoj oblasti [Anthropological research in the Kamchatka region]. Trudy Severo-vostochnoj ekspedicii, 1. Moscow: Izd-vo 
Akademii nauk SSSR.

Dodo Yukio, at all. 2001. Metric Data of Ryukyunan Crania. Anthropological Sciense 109 (2): 182-190.

Hambly, Wielfred D. 1946. Craniology of Ambrim Island. Fieldiana: Anthropology 37 (1): 1-46. Chicago.

Harrower, Gordon. 1925. A Study of the Hakian and Tamil Scull, 1-31. Singapore: Appendix.

Howells, W.W. 1995 Who`s Who in Skulls. Ethnic Identification of Crania from Measurements.

Papers of the Peabody Museum of Archaeology and Ethnology 82: 108. Cambridge, Mass.: Peabody Museum.

Howells, W.W. Craniometric data set. http://web.utk. edu/ auerbach/HOWL.htm.

Hrdlicka, A. 1928. Catalogue of human crania in the United States national museum collectilns. Procceedings of the of the United States national museum 71.Washington.

Morant, G. M. 1924. A Study of certain series including the Nepalese and Tibetan series in the British Museum (Natural History). Biometrika 16, 1/2 (May 1924): 1-105.

Newman, M.T. 1949. The Sequence of Indian Physical Types in South America // Papers on the

Physical Anthropology of the American Indian 21: 69-97. New York.

Pestriakov, A.P., and O.M Grigoryeva. 2004. Kraniologicheskaia differentsiatsiia sovremennogo naseleniia [The craniological differentiation of the contemporary population]. In: Rasy i narody, 30: 86-131. Moscow: Nauka.

Pestryakov, A.P., and O.M Grigoryeva.2011. Nekotorye dannye po kraniologii naseleniya Yaponskih ostrovov [Some data on the craniology of the population of the Japanese Islands]. Vestnik antropologii. Nauchnyj al'manah 20: 23-35.

Pestryakov, A.P., and O.M Grigoryeva. 2013. Avstralijskie aborigeny na kraniologicheskom fone naseleniya YUzhnoj i YUgo-vostochnoj Azii i Zapadnoj Okeanii [Australian aborigines on the craniological background of the population of South and South-East Asia and Western Oceania]. //Vestnik Moskovskogo universiteta. Seriya Antropologiya, XXIII, 2: 17-33. Moscow.

Tidesley, M.L. 1921. A first Study of Burmese Skull. Biometrika. 13, 2/3 (Jul. 1921): 176-262. 